\title{
O (PÓS-)POSITIVISMO E OS PROPALADOS MODELOS DE JUIZ (HÉRCULES, JÚPITER E HERMES) - DOIS DECÁLOGOS NECESSÁRIOS
}

\author{
Lenio Luiz Streck*
}

\section{RESUMO}

Já virou lugar comum dizer que se é pós-positivista. Entretanto, pouco se sabe o que realmente seja o positivismo jurídico (em suas várias facetas), confundindo esse movimento com a mera aplicação da literalidade da lei. Nesse sentido, não se pode admitir argumentos que afastam o conteúdo de uma lei, democraticamente legitimada, com base numa suposta "superação" da literalidade do texto legal. Desse modo, para verificar o papel do intérprete do direito, faz-se necessária a desconstrução de uma tese que vem servindo de base para a caracterização dos modelos de direito e de juiz nos diversos sistemas jurídicos contemporâneos, os conhecidos juízes Hércules, Júpiter e Hermes (Ost), que tem levado a diversos e diferentes equívocos na teoria do direito. Uma reflexão crítica sobre a aplicação do direito não pode abrir mão dos pressupostos hermenêuticos que apontam para a superação dos "modelos" (solipsistas) de juiz "criados" para "enfrentar" as agruras da indeterminabilidade dos textos jurídicos. Kelsen, Hart e Ross foram todos positivistas. Como

\footnotetext{
* Professor titular da UNISINOS; visitante/colaborador da UNESA-RJ, ROMA-TRE, FDUC (Portugal); membro catedrático da ABDCONST; coordenador do DASEIN - Núcleo de Estudos Hermenêuticos; pós-doutor em Direito (FDUL - Portugal). Procurador de Justiça-RS. Editor do site: www.leniostreck.com.br.
} 
positivistas são hoje os juristas que apostam em ativismos e na discricionariedade judicial...!

Palavras-chave: Positivismo. Modelos de Juiz. Juiz Hércules. Juiz Júpiter. Juiz Hermes. François Ost. Ronald Dworkin. Hermenêutica Filosófica.

\section{ABSTRACT}

Has become commonplace to say that it is post-positivist. However, little is known about what really is legal positivism (in its various facets), mistaking this movement with the mere literal application of the law. In this sense, we can not accept arguments that drive the content of a law, with democratic legitimacy, based on a supposed "overcoming" the literalness of the text. Thus, to verify the role of interpreter of the law, it is necessary to deconstruct a thesis that has been serving as the basis for the characterization of the model law and a judge in many contemporary legal systems, the well-known judges Hercules, Jupiter and Hermes (Ost), which has led to many misunderstandings and different in legal theory. A critical reflection on the application of law can not give up the hermeneutical presuppositions that link to overcome the "models" (solipsist) to judge "created" to "confront" the hardships of the indeterminacy of legal texts. Kelsen, Hart and Ross were all positivists, as well as the jurists that are now betting on activism and judicial discretion ...!

Keyword: Legal Positivism. Models of Judges. Judge Hercules. Judge Jupiter. Judge Hermes. François Ost. Ronald Dworkin. Philosophical Hermeneutics.

\section{DE ONDE EXSURGEM OS EQUÍVOCOS ACERCA DO QUE SEJA A “INTERPRETAÇÃO DA LEI" E DOS “DILEMAS DO POSITIVISMO" (OU DO PÓS- POSITIVISMO)}

O que será "isto", o "positivismo jurídico"? Trata-se de uma das indagações mais relevantes a se fazer na área do direito. Tão importante que, fôssemos médicos, estaríamos falando do funcionamento do coração. Pois o positivismo é, por assim dizer, queiramos ou não, o 
"coração do direito" (no mínimo no tocante ao estudo da complexidade do fenômeno). O que quero dizer é que há algo na teoria do direito (e na sua operacionalidade) que, historicamente, tem sido a sua condição de possibilidade. Em síntese, é "onde tudo começou".

Nesta quadra da história, (quase) todos se consideram pós-positivistas. Daí a minha insistente pergunta, que venho procurando responder em livros como $\mathrm{O}$ que é isto - decido conforme minha consciência (Livraria do Advogado, 2010), Verdade e Consenso (Lumen Juris, 2009 e Saraiva, 2011) e Hermenêutica Jurídica e(m) Crise (10. ed., Livraria do Advogado, 2011): que coisa é essa - o positivismo? Ouvem-se muito, em sala de aula, conferências e seminários, críticas ao positivismo. E aí vem a simplificação: basta alguém defender a aplicação de um determinado texto jurídico é logo taxado de "positivista". Isso é absolutamente comum. Defender a aplicação da "literalidade" de uma lei, por exemplo, passou a ser um pecado mortal. O epíteto de positivista fica brilhando como em um outdoor na testa do jurista que ousa fazer tal defesa. Mas fazer a defesa da "literalidade da lei" seria uma atitude positivista?

Quando falamos em positivismos e pós-positivismos, tornase necessário, já de início, deixar claro o "lugar da fala", isto é, sobre "o quê" estamos falando. Passo por essa experiência cotidianamente. Permito-me explicar isso melhor: há muito as minhas críticas tem tido como alvo o positivismo pós-exegético, isto é aquele positivismo que superou o positivismo das três vertentes (exegese francesa, pandectística alemã e jurisprudência analítica da common law). Ou seja, sempre considerei muito simplista reduzir a crítica do direito a uma simples superação do deducionismo legalista (e os nomes que a isso se dê). Portanto, tenho apontado minhas baterias contra a principal característica do positivismo pós-exegético, qual seja, a discricionariedade. Curiosamente, juristas das mais variadas facções diziam (e isso ainda acontece): se você é contra a discricionariedade dos juízes, então defende o legalismo, o exegetismo, o juiz boca da lei... Que coisa, não? E complementa(va)m: aceitamos a discricionariedade, mas não a arbitrariedade... (como se os "limites semânticos" tivessem contornos "tão definidos" como pretendem especialmente as teorias analíticas do direito). Um jusfilósofo muito conhecido chegou a me acusar, em um 
Congresso realizado além-mar, que eu estava defendendo "a proibição de interpretar". Na verdade, confesso que, nos últimos anos, cometi o seguinte equívoco: não me dei conta que os juristas brasileiros (e nisso se incluem os neoconstitucionalistas da península ibérica que não abrem mão da discricionariedade judicial), contenta(va)m-se com o menos, isto é, limita(va)m-se a superar as velhas formas de exegetismo, entregando, entretanto, todo o poder ao intérprete (em especial, aos juízes), a partir de uma série de fórmulas do tipo "menos regras, mais princípios, menos subsunção, mais ponderação", etc.

Ora, convenhamos, essa "entrega" (ou seria "delegação"?) do poder aos juízes (e, portanto, em favor da discricionariedade interpretativa) não é nem um pouco nova, eis que já estava presente no velho Movimento do Direito Livre, na jurisprudência dos interesses e se aprimorou na jurisprudência dos valores (sem considerar os movimentos realistas no interior da common law). Qual é o problema, então? Na verdade, o que aconteceu é que os juristas se esqueceram que Kelsen e Hart promoveram, em sistemas jurídicos distintos, uma virada no positivismo. De todo modo, importa mais para nós a viragem kelseniana, que acabou impulsionando um voluntarismo judicial sem precedentes, a partir da "maldição kelseniana" constante no famoso capítulo oitavo da Teoria Pura do Direito.

Derrotar o positivismo (exegético) e pagar o preço do voluntarismo foi (e ainda é) uma vitória de pirro. Por isso, minha luta contra os sintomas dessa viragem positivista (normativista). Não posso concordar com o fato de que a crítica contemporânea não consiga fazer mais do que já fizera a jurisprudência dos interesses ou a jurisprudência dos valores. Da condição de refém de um assujeitamento a uma estrutura de caráter objetivista (metafísica clássica presente na ideia exegética e pandectista), passou-se a fase do "assujeitamento da estrutura a um sujeito solipsista”. Enfim, do "aprisionamento" do intérprete a um sistema racional-conceitual, passamos ao império da vontade (do poder), último princípio epocal da modernidade. Não é por nada que, para Kelsen, a interpretação feita pelos juízes é um ato de vontade. 
Permito-me insistir neste ponto um pouco mais. Com efeito, há muito minhas críticas são dirigidas primordialmente ao positivismo normativista pós-kelseniano, isto é, ao positivismo que admite discricionariedades (ou decisionismos e protagonismos judiciais). Considero superado o velho positivismo exegético. Ou seja, não é (mais) necessário dizer que o "juiz não é a boca da lei", etc., enfim, podemos ser poupados, nesta quadra da história, dessas "descobertas da pólvora". E isso por uma razão muito simples: essa "descoberta" não pode implicar um império de decisões solipsistas, das quais são exemplos as posturas caudatárias da jurisprudência dos valores (que foi "importada" por setores do neoconstitucionalismo de forma equivocada da Alemanha), os diversos axiologismos, o realismo jurídico (que não passa de um "positivismo fático"), a ponderação de valores ${ }^{2}$ (pela qual, especialmente no Brasil, a partir de uma leitura superficial da obra de Alexy, o juiz literalmente escolhe um dos princípios que ele mesmo elege prima facie), etc.

Portanto, Kelsen superou o positivismo exegético-primevo-legalista. Mas, vejamos: Kelsen não pretendeu destruir a tradição positivista que foi construída pela jurisprudência dos conceitos. Pelo contrário, é possível afirmar que seu principal objetivo era reforçar o método analítico proposto pelos conceitualistas de modo a responder ao crescente desfalecimento do rigor jurídico que estava sendo propagado pelo crescimento da Jurisprudência dos Interesses e da Escola do Direito Livre - que favoreciam, sobremedida, o aparecimento de argumentos psicológicos, políticos e ideológicos na interpretação do direito. Isso é feito por Kelsen a partir de uma radical constatação: o problema da interpretação do direito é muito mais semântico do que sintático. Desse modo, temos aqui uma ênfase na semântica. ${ }^{3}$

Mas, em um ponto específico, Kelsen "se rende" aos seus adversários: a interpretação do direito é eivada de subjetivismos provenientes de uma razão prática solipsista. Para o autor austríaco, esse "desvio" é impossível de ser corrigido. No famoso capítulo VIII de sua Teoria Pura do Direito, Kelsen chega a falar que as normas jurídicas entendendo norma no sentido da TPD, que não equivale, stricto sensu, à lei - são aplicadas no âmbito de sua "moldura semântica". O único modo de corrigir essa inevitável indeterminação do sentido do direito 
somente poderia ser realizada a partir de uma terapia lógica - da ordem do a priori - que garantisse que o Direito se movimentasse em um solo lógico rigoroso. Esse campo seria o lugar da Teoria do Direito ou, em termos kelsenianos, da Ciência do Direito. E isso possui uma relação direta com os resultados das pesquisas levadas a cabo pelo Círculo de Viena.

Esse ponto é fundamental para podermos compreender o positivismo que se desenvolveu no século XX e o modo como encaminho minhas críticas nessa área da teoria do direito. Sendo mais claro: falo desse positivismo normativista, não de um exegetismo que, como pôde ser demonstrado, já havia dado sinais de exaustão no início do século passado. Numa palavra: Kelsen já havia superado o positivismo exegético, mas abandonou o principal problema do direito - a interpretação concreta, no nível da "aplicação". E nisso reside a "maldição" de sua tese. Não foi bem entendido, quando ainda hoje se pensa que, para ele, o juiz deve fazer uma interpretação "pura da lei"...!

Numa palavra: quando falo, por exemplo, em "literalidade", não estou invocando nem o positivismo primitivo (exegético) e nem o positivismo normativista. Ora, desde o início do século XX, a filosofia da linguagem e o neopositivismo lógico do círculo de Viena já haviam apontado para o problema da polissemia das palavras. Isso nos leva a outra questão: a literalidade é algo que está à disposição do intérprete? Se as palavras são polissêmicas; se não há a possibilidade de cobrir completamente o sentido das afirmações contidas em um texto, quando é que se pode dizer que estamos diante de uma interpretação literal? A literalidade, portanto, é muito mais uma questão da compreensão e da inserção do intérprete no mundo do que uma característica, por assim dizer, natural dos textos jurídicos.

Dizendo de outro modo, não podemos admitir que, ainda nessa quadra da história, sejamos levados por argumentos que afastam o conteúdo de uma lei - democraticamente legitimada - com base numa suposta "superação" da literalidade do texto legal. Insisto: literalidade e ambiguidade são conceitos intercambiáveis que não são esclarecidos numa dimensão simplesmente abstrata de análise dos signos que compõem um enunciado. Tais questões sempre remetem a um plano 
de profundidade que carrega consigo o contexto no qual a enunciação tem sua origem. Esse é o problema hermenêutico que devemos enfrentar! Problema esse que argumentos despistadores como tal só fazem esconder e, o que é mais grave, com riscos de macular o pacto democrático.

\section{OS MODELOS DE JUIZ E A DETERMINAÇÃO DO PAPEL DO INTÉRPRETE NO DIREITO OU “DE COMO NÃO SE PODE EXAMINAR OS “MODELOS” SEM LEVAR EM CONTA AS DIMENSÕES PARA- DIGMÁTICAS DECORRENTES DO ESQUEMA SU- JEITO-OBJETO"}

Na linha do que foi dito acima, para uma melhor compreensão acerca do papel do intérprete do direito nesta quadra da história, fazse necessária a desconstrução de uma tese que vem servindo de base, há muito, para a caracterização dos modelos de direito e de juiz nos diversos sistemas jurídicos contemporâneos, o que tem levado a diversos e diferentes equívocos na teoria do direito. Essa questão tem uma relação umbilical com a questão da democracia e da divisão de poderes, na medida em que a jurisdição constitucional afetará essa problemática de acordo com aquilo que se pode denominar de teoria da decisão e o papel a ser exercido pelo juiz.

Uma discussão que atravessa os anos institucionalizou os modelos de juiz, como sendo Júpiter, Hércules, Hermes, a partir de um conhecido texto de François Ost (1993, pp. 170-194), em que o professor belga propõe uma espécie de juiz pós-moderno-sistêmico (Hermes) que atuaria em rede e superaria, com grande vantagem, os "modelos anteriores". Com efeito, para Ost, basicamente a teoria do direito trabalha com dois modelos de juiz, que também simboliza(ria)m "modelos de direito" (Júpiter e Hércules). Consequentemente, simbolizaram também os modelos de jurisdição. O primeiro representaria o modelo liberal-legal, de feição piramidal-dedutivo, isto é, sempre dito a partir do alto, de algum "Monte Sinai"; esse direito adota a forma de lei e se expressa em forma de imperativo, vindo a ser representado pelas 
tábuas da lei ou códigos e as Constituições modernas, sendo que dessa parametricidade é que são deduzidas as decisões particulares.

Já o modelo herculeano está sustentado na figura do juiz, que seria a única fonte do direito válido. Trata-se de uma pirâmide invertida, no dizer de Ost. É Dworkin quem, no dizer do autor, ao revalorizar até o extremo a figura do juiz moderno, atribui-lhe as características de Hércules. Embora diga que não pretende "equiparar" a tese de Dworkin aos realistas ou pragmatistas, Ost termina por colocar no Hércules dworkiano os "defeitos" que caracterizariam o juiz "monopolizador da jurisdição" no modelo de direito do Estado Social, em que o direito "se reduz ao fato", enfim, à indiscutível materialidade da decisão. Esse juiz propiciaria um deciosionismo, a partir da proliferação de decisões particulares.

Como contraponto, Ost apresenta um tertius genus, o juiz Hermes, que adota a forma de rede; nem um polo, nem dois, isto é, nem a pirâmide e nem um funil, e tampouco a superposição dos dois, senão uma multiplicidade de pontos de inter-relação; um campo jurídico que analisa como uma combinação infinita de poderes, tanto separados como confundidos, amiúde intercambiados; uma multiplicação dos atores, uma diversificação de regras, uma inversão de réplicas; tal circulação de significados e informações não se deixa aprisionar em um código ou em uma decisão: expressa-se sob a forma de um banco de dados. Assim, segundo Ost, o direito pós-moderno, o direito de Hermes, é uma estrutura em rede que traduz em infinitas informações disponíveis instantaneamente e, ao mesmo tempo, dificilmente matizáveis. Trata-se, em síntese, de uma teoria lúdica do direito. O juiz Hermes não é nem transcendência nem imanência; encontra-se em uma e outra dialética ou paradoxalmente (uma e outra).

Penso que, examinada à luz da hermenêutica filosófica e do neoconstitucionalismo, assim como a partir das diversas teorias do direito surgidas no século XX, a tese de Ost merece uma série de objeções, não tanto na parte em propõe o Hermes como solução (que, a toda evidência, apresenta aspectos de grande relevância), mas, fundamentalmente, em relação às críticas ao "modelo herculeano".

Assim, em primeiro lugar, a objeção decorre do fato de haver um excessivo esforço em enquadrar o "modelo herculeano" no modelo de 
direito do Estado Social, colocando-o como uma antítese do juiz que caracterizaria o modelo de Estado Liberal (o modelo jupteriano), como se o modelo do "juiz do estado Liberal" fosse o juiz do positivismo primitivo (fase exegética do positivismo) e o segundo fosse o do modelo que simplesmente supera esse modelo, ou seja, no primeiro o "juiz seria a boca da lei" e seu superador seria o "juiz que faz a lei" ...! Como veremos, isso constitui um equívoco.

A objeção seguinte decorre do fato de Ost não levar em conta que o juiz Hércules é uma metáfora e que representa exatamente o contrário do que sua tese pretende denunciar, isto é, Hércules definitivamente não é a encarnação do "juiz/sujeito-solipsista", mas sim, é a antítese do juiz discricionário, este sim refém da filosofia da consciência (essa discussão, lamentavelmente, não aparece no texto, talvez porque a atuação de Hermes "em rede" supere, na tese de Ost, o "sujeito da relação"). ${ }^{4}$

Como terceira objeção, a tese peca também porque tudo aquilo que Ost aponta como missões do Hércules "assistencialista" (v.g., "conciliar as economias familiares em crises; dirigir as empresas em dificuldades evitando, se possível, a quebra; julgar se corresponde ao interesse da criança ser reconhecido pelo seu pai natural, quando a mãe se opõe - art. 319.3 do Código Civil da Bélgica; apreciar se a interrupção voluntária da gravidez pode ser justificada pelo "estado de angústia" da mulher grávida - art. 348 e seguintes do Código Penal belga; intervir efetivamente em conflitos coletivos de trabalho e decidir, em procedimentos de urgência, se a greve dos pilotos da companhia de aviação nacional, prevista para o dia seguinte às seis horas, é lícita ou não; julgar se o aumento de capital decidido com o objetivo de opor-se a uma oferta pública de compra de uma holding, cuja carteira de ações representa um terço da economia do país, está em conformidade com a lei; ou, ainda, impor sanções a trabalhadores e empresas que ameaçam o equilíbrio ecológico") também pode ser feito sem que o juiz ou o tribunal pratique decisionismos ou arbitrariedades (ou assistencialismos), ou seja, Ost esquece que a coerência e a integridade - própria do modelo dworkiano - constituem-se em blindagem contra aquilo que Ost acredita ser característica do modelo herculeano. Na sequência, em quarto lugar, Ost não comenta os efeitos colaterais e as consequências para o próprio constitucionalismo de um "não intervencionismo" do 
judiciário (ou justiça constitucional) para atender os pleitos sobre direitos fundamentais (e os exemplos tratam das mais variadas formas de violação de direitos).

Em quinto lugar, ao dizer que, "na gestão do juiz Hércules", a generalidade e a abstração da lei dão lugar à singularidade e à concretude do juízo, o professor belga passa a impressão de que, mesmo nesta quadra do tempo, ainda vivemos sob a égide do velho modelo de regras, como se não tivesse ocorrido a revolução copernicana do neoconstitucionalismo (ou, se houve alguma ruptura, essa fica, na opinião de Ost, reduzida ao modelo de direito do estado Social). Ao que tudo indica, para ele, os princípios não são "os princípios" que institucionalizaram stricto sensu a moral no direito (o ideal de vida boa, o "bom direito") a partir da produção democrática (Constituições compromissórias e dirigentes), não havendo sinais, na aludida tese, sobre o papel da moral no Estado Democrático de Direito. Ao contrário, as indicações da tese de Ost, no particular, são de que os princípios são aqueles "gerais do direito", que têm a função de otimizar a interpretação, fechando e abrindo, autopoieticamente, o sistema jurídico.

Isso leva à sexta objeção, representada pelo reducionismo que o autor pretende fazer dos modelos de direito e de juiz. Com efeito, o que fazer com o juiz "ponderador" de Alexy, que, nos "casos difíceis" - não solucionáveis por subsunção - apela para um sopesamento (sic) entre os princípios que estão em colisão? E os juízes analíticos, característicos de modelos metodológicos apresentados por Áurnio e MacCormick, para citar apenas estes? E qual o papel do juiz exsurgente da teoria do discurso desenvolvido por Habermas (1992)?

O sétimo ponto de discórdia diz com o fato de que a tese de Ost ignora (passa ao largo) (d)o paradigma do Estado Democrático de Direito, entendido como um plus normativo e qualitativo superador dos modelos de direito liberal e social, circunstância que faz com que não leve em conta o papel do constitucionalismo enquanto rompimento com o positivismo e o modelo de regras; prova disso é a observação que faz, baseado em texto de 1990, de André Jean Arnaud", de que "filósofos, teóricos e sociólogos se esforçam atualmente para substituir o direito rígido, fundado sobre a toda poderosa lei, por um direito flexível 
que toma em conta o relativismo, o pluralismo e o pragmatismo característicos da época pós-moderna", como se a teoria do direito não tivesse avançado para (muito) além desse debate acerca da superação do "modelo do direito rígido fundado na toda poderosa lei" e a dicotomia "monismo-pluralismo". Veja-se que o próprio Ost diz que "ao monismo haveria-se de opor, não a dispersão, mas sim, o pluralismo, o absolutismo binário permissão-proibição, válido-não válido, haveria que substituir pelo relativismo e o gradualismo, que não se transforma, por isso, em ceticismo".

A oitava divergência se instaura porque a tese de Ost passa ao largo do enfrentamento entre positivismo e constitucionalismo e, consequentemente, da superação do modelo subsuntivo e da distinção (não lógico-estrutural, é claro) entre regra e princípio. E tal circunstância não pode escapar de qualquer discussão acerca do direito nesta quadra da história.

Nono, porque, ao propor o modelo de Hermes como um avanço em relação ao convencionalismo de Júpiter e ao "invencionismo" de Hércules, isto é, ao afirmar que o seu juiz Hermes respeita o caráter hermenêutico ou reflexivo do raciocínio jurídico, que, portanto, não se reduz nem à imposição e nem à simples determinação anterior, o Hermes de Ost acaba sendo, paradoxalmente, o Hércules de Dworkin (obviamente na leitura que Ost faz do Hércules dworkiniano). Do mesmo modo, ao dizer que as fronteiras que separam o sistema e seu meio ambiente não deixam de ser móveis e paradoxais, como se os limites do direito e do não direito fossem reversíveis, Ost faz concessões ao Hércules que ele mesmo critica (afinal, como ele mesmo diz, um jogo, como o direito, é sempre, ao mesmo tempo, algo mais que ele mesmo, apesar dos esforços desenvolvidos para uniformizar seu funcionamento e pormenorizar seus dados).

Por fim, em décimo lugar, em relação à crítica de Ost de que, afora o fato de que tanto o modelo jupiteriano como o modelo herculeano estão em crise, "eles apenas oferecem representações empobrecidas da situação que pretendiam descrever em sua época", lembro que não se pode cair em idealizações ou idealismos, como se fosse possível ignorar que o paradigma do Estado Democrático de Direito e o tipo de constitucionalismo instituído em grande parte dos países após o segundo pós-guerra aumentou sobremodo a demanda pela intervenção 
do poder judiciário (ou da justiça constitucional, na forma de Tribunais Constitucionais). Ora, isso apenas implica reconhecer que é inexorável que "alguém decida", até para não transformar a Constituição em uma "mera folha de papel".

Assim, em síntese, contrapor o modelo de Hermes ${ }^{6}$ aos modelos de Júpiter (Estado Liberal) e Hércules (Estado Social) apenas comprova o grande dilema que atravessa a metodologia contemporânea: como se interpreta e como se aplica, isto é, quais as condições que tem, o juiz ou tribunal (porque, permito-me insistir no óbvio, alguém tem que dizer por último o sentido da Constituição), para proferir as respostas aos casos em julgamento.

Não parece adequada, portanto, a tese da contraposição do modelo de direito do Estado Social ao modelo de direito do Estado Liberal. Isso seria ignorar os dois pilares sobre as quais está assentado um terceiro modelo, o do Estado Democrático de Direito: a proteção dos direitos sociais-fundamentais e o respeito à democracia.

Em outras palavras, se é inexorável que, a partir do segundo pós-guerra, diminui o espaço de liberdade de conformação do legislador em favor do controle contramajoritário feito a partir da jurisdição constitucional, é exatamente por isso que devem ser construídas as condições de possibilidade para evitar discricionariedades, arbitrariedades e decisionismos, ou seja, o constitucionalismo destes tempos pós-positivistas assenta seus pilares no novo paradigma linguístico-filosófico, superando quaisquer possibilidades de modelos interpretativos (se quiser, hermenêuticos) sustentados no esquema sujeito-objeto.

É, portanto, desse modo que se busca a superação do velho positivismo. E é por isso mesmo que o Hércules de Dworkin não pode ser epitetado de "invencionista" ou "solipsista" (ou qualquer variação realista ou pragmatista). Do mesmo modo - embora essa questão não esteja abarcada pelo texto de Ost - a busca de respostas corretas em direito não pode sofrer críticas porque estaria assentado em um juiz que "carregaria o mundo nas costas". Ao contrário, pela simples razão de que a busca de respostas corretas é um remédio contra o cerne do modelo que, dialeticamente, engendrou-o: o positivismo e sua característica mais forte, a discricionariedade. 
Não há um Hércules no modelo da hermenêutica aqui trabalhado (não podemos esquecer que o Hércules de Dworkin instala-se na teoria do direito para demonstrar que a discricionariedade é antidemocrática e que, ao rejeitar qualquer posição pessoal do juiz e colocar ênfase na sua responsabilidade política, superou o esquema sujeito-objeto). Na hermenêutica filosófica aqui professada, o círculo hermenêutico "atravessa" a compreensão antes que o sujeito pense que se assenhora da interpretação e dos sentidos. Por isso, a resposta correta que sempre pode e deve ser encontrada não reside no juiz/intérprete enquanto sujeito do "esquema sujeito-objeto", mas sim, no juiz/intérprete da relação de compreensão baseada na intersubjetividade (sujeito-sujeito). Assim, o ponto fulcral não é quem dá a resposta correta, mas como esta se dá.

\section{DA METÁFORA DO JUIZ (HÉRCULES) À METÁFORA DA RESPOSTA (CORRETA) OU DE COMO A RESPOSTA CORRETA DEVE SER COMPREENDIDA COMO UMA METÁFORA}

Frente ao estado da arte representado pelo predomínio do positivismo, que sobrevive a partir das mais diversas posturas e teorias sustentadas, de um modo ou de outro, no predomínio do esquema sujeito-objeto - problemática que se agrava com uma espécie de protagonismo do sujeito-intérprete (especialmente, juízes e tribunais) em pleno paradigma da intersubjetividade - penso que, mais do que possibilidade, a busca de respostas corretas em direito é uma necessidade.

Por isso, a resposta correta que venho propondo $\mathrm{p}^{7}$, a partir de uma simbiose entre a teoria integrativa de Dworkin ${ }^{8}$ e a fenomenologia hermenêutica (que abarca a hermenêutica filosófica), deve ser entendida como uma metáfora. ${ }^{9}$ Afinal, metáforas servem para explicar coisas. Isso, à evidência, implica pensar esse modelo dentro de suas possibilidades. Com efeito, metáforas são criadas porque se acredita que um determinado fenômeno poderá ser melhor explicado a partir da explicação já consolidada de um outro fenômeno, ou seja, a "operação com que transferimos significados não-sensíveis para imagens ou remetemos elementos sensíveis a esferas não-sensíveis" ${ }^{\prime \prime}$. Portanto, 
se considerarmos que essa distinção fundamental entre sensível e nãosensível não existe, a colocação da metáfora representa uma atitude tipicamente metafísica, induzindo o agente a compreendê-la como um ponto de partida universal.

Contudo - e essa advertência reveste-se de fundamental relevância, para não gerar mal-entendidos -, se a metáfora for pensada dentro das limitações de uma linguagem apofântica, que terá sempre como pressuposto a dimensão hermenêutica da linguagem, ela permitirá, a exemplo do neologismo, uma aproximação entre o dito e o fenômeno já compreendido, uma vez que nela encerra, como já foi visto, um grau de objetivação minimamente necessário. A metáfora é entendida, assim, como a possibilidade, a partir da diferença ontológica, de "ligar" significantes e significados. A metáfora significa a impossibilidade de sinonímias "perfeitas".

A metáfora da resposta correta será, desse modo, a explicitação de que é possível atravessar o "estado de natureza hermenêutica" instalado no direito. A metáfora nos mostra que, ao nos situarmos no mundo, isso não implica um genesis a cada enunciação. Dito de outro modo, pela metáfora da resposta correta - compreendida nos moldes aqui delimitados - estabelece-se a convicção (hermenêutica) de que há um desde-jásempre (existencial) que conforma o meu compromisso minimamente objetivado(r), uma vez que, em todo processo compreensivo, o desafio é levar os fenômenos à representação ou à sua expressão na linguagem, chegando, assim, ao que chamamos de objetivação, como sempre nos lembra Ernildo Stein.

A construção da metáfora da resposta correta deita raízes em outra metáfora. Com efeito, Hobbes criou a metáfora do contrato social para explicar a necessidade de superar a barbárie representada pela fragmentação do medievo. Mas, mais do que isso, fê-lo para demonstrar que o Estado é produto da razão humana. Para tanto, contrapôs a soberania "do um" para superar a soberania fragmentada/ dilacerada "de todos", isto é, contra a barbárie representada pelo Estado de Natureza, contrapôs a civilização. E isso somente seria possível através de um contrato. Não um contrato stricto sensu, mas um "contrato metafórico".

Penso que, de algum modo, é necessário enfrentar o "estado de natureza hermenêutica" em que se transformou o sistema jurídico. A 
"liberdade" na interpretação dos textos jurídicos proporcionada pelo império das correntes (teses, teorias) ainda arraigadas/prisioneiras do esquema sujeito-objeto tem gerado esse "estado de natureza interpretativo", representado por uma "guerra de todos os intérpretes contra todos os intérpretes", como que repristinando a fragmentação detectada tão bem por Hobbes. Cada intérprete parte de um "grau zero" de sentido. Cada intérprete reina nos seus "domínios de sentido", com seus próprios métodos, metáforas, metonímias, justificativas, etc. Os sentidos "lhe pertencem", como se estes estivessem a sua disposição, em uma espécie de reedição da "relação de propriedade" (neo)feudal. Nessa "guerra" entre os intérpretes - afinal, cada um impera solipsisticamente nos seus "domínios de sentido" - reside a morte do próprio sistema jurídico.

Por tais razões é que a tese da resposta correta em um sistema "não avançado" (lembremos a observação de Dworkin sobre a temática, com a qual não é possível concordar) não é uma possibilidade, e sim, uma necessidade. Como já explicitado anteriormente, isso implica a superação do esquema sujeito-objeto, a partir dos dois teoremas fundamentais da hermenêutica: o círculo hermenêutico e a diferença ontológica. Com isso, ultrapassa-se qualquer possibilidade da existência de grau(s) zero(s) de sentido - que se sustentam naquilo que venho denominando de "ideologia do caso concreto" -, resgatando a tradição autêntica (sentido da Constituição compreendido como o resgate das promessas da modernidade) e reconstruindo, a partir dessas "premissas", em cada caso, a integridade e a coerência interpretativa do direito.

A resposta correta é uma metáfora, como o juiz Hércules de Dworkin também o é. Para tanto - e aqui vai uma advertência indispensável -, a ruptura com o "estado de natureza hermenêutica" não se dará através de uma delegação em favor de uma instância última, isto é, um "abrir mão do poder de atribuir sentidos em favor de uma espécie de Leviatã hermenêutico".

Dito de outro modo, se a resposta para a fragmentação do estado de natureza medieval foi a delegação de todos os direitos em favor do Leviatã representado pela soberania absoluta do Estado (o Estado Moderno absolutista superou, desse modo, a forma estatal medieval), 
na hermenêutica jurídica de cariz positivista, a resposta para o império dos subjetivismos, axiologismos, realismos ou o nome que se dê a tais posturas - que colocam no intérprete (juiz, tribunal) o poder discricionário de atribuir sentidos - não pode ser, sob hipótese alguma, a instauração de uma supra-hermeneuticidade ou a delegação dessa função para uma super-norma que possa "prever todas as hipóteses de aplicação", que, mutatis, mutandis, é a pretensão última das súmulas vinculantes. Assim, contra o caos representado pelos decisionismos e arbitrariedades, o establishment propõe um "neo-absolutismo hermenêutico".

Sendo mais claro, as súmulas vinculantes - do modo como são compreendidas pela dogmática jurídica (senso comum teórico) - encarnam essa instância controladora de sentidos metafisicamente, isto é, através delas, acredita-se que é possível lidar com conceitos sem as coisas, sem as peculiaridades dos casos concretos (o inusitado nisso é que, paradoxalmente, o império das múltiplas respostas se instaurou, exatamente, a partir de uma analítica de textos em abstrato). As súmulas constituem uma espécie de "adiantamento de sentido", uma "tutela antecipatória de palavras"...!

Não esqueçamos que as súmulas são decisões de caráter aditivo/ manipulativo. Afinal, não existe súmula que refira, por exemplo, que determinado dispositivo é inconstitucional, pela simples razão de que, se tal dispositivo efetivamente fosse inconstitucional, teria sido assim declarado (ou isso ou teremos que aceitar uma certa esquizofrenia em nosso sistema jurídico). Vale lembrar que sempre houve no sistema um considerável número de súmulas enquadráveis como contra legem/inconstitucionais e extra legem. Os tribunais, quotidianamente, constroem normas jurídicas, através de novos textos (além da construção stricto sen$s u$ de novos textos legais, os tribunais efetuam forte atividade corretiva, o que se pode ver, v.g., no julgamento do HC n. 72862-6), ${ }^{10}$ que sequer necessitam ser transformadas em súmulas, alterando o ordenamento jurídico, sem que isto cause perplexidade no imaginário dos juristas. Na realidade, tais decisões somente causam perplexidade - e só então a questão é trazida para a discussão da dicotomia jurisdição-legislação e suas consequências - quando determinadas decisões interpretativas (seja a classificação que se dê) mostram-se em desconformidade com o teto herme- 
nêutico preestabelecido pela doutrina e pela jurisprudência. Ou seja, o limite do sentido e o sentido do limite ficam adstritos àquilo que o sentido comum aceita como possibilidade construtiva.

Da maneira como são compreendidas as súmulas vinculantes no interior do imaginário metafísico-positivista, estas se colocam como sucedâneos dos conceitos universais próprios da metafísica clássicaessencialista, justamente combatida por Hobbes (para não perder o valor da metáfora que fundamentou a superação da forma de dominação medieval), com a agravante, aqui, de que elas são criadas a partir de uma institucionalização de subjetivismos, axiologismos e realismos (todas variantes do esquema sujeito-objeto).

Forma-se, desse modo, um círculo vicioso: primeiro, admite-se discricionarismos e arbitrariedades em nome da "ideologia do caso concreto", circunstância que, pela multiplicidade de respostas, acarreta um sistema desgovernado, fragmentado; na sequência, para controlar esse caos, busca-se construir conceitos abstratos com pretensões de universalização, como se fosse possível uma norma jurídica abarcar todas as hipóteses (futuras) de aplicação.

Isso permite afirmar que, na verdade, o combate ao "estado de natureza hermenêutica" originário da discricionariedade/arbitrariedade positivista acaba não sendo um combate ao positivismo. Ao contrário, destituído de uma adequada compreensão hermenêutica, a partir dos seus dois teoremas fundamentais, qualquer forma de vinculação jurisprudencial, por mais paradoxal que possa parecer, somente reforçará o positivismo, com a conseqüente continuidade do caos decisionista. Ou seja, na medida em que súmulas são textos e como o positivismo interpreta textos sem coisas, qualquer tentativa de vinculação jurisprudencial/conceitual receberá uma adaptação darwiniana do senso comum teórico dos juristas.

Neste ponto, cabe outra advertência: a afirmação de que a súmula é (também) um texto deve ser compreendida a partir de um olhar hermenêutico. Destarte, quando afirmo que a súmula é um texto, quero dizer que esse texto, ao ser interpretado, deverá ensejar uma norma (sentido) que respeite, de forma radical, a coerência e integridade do direito. Caso contrário, ela será aplicada de forma objetificada, entifi- 
cadamente, isto é, será uma categoria a partir da qual se fará deduções e subsunções.

Ora, na medida em que a súmula é feita para resolver casos futuros - e nisso reside um equívoco hermenêutico de fundamental importância, em uma simples comparação com os precedentes norteamericanos -, transformando hard cases em (futuros) easy cases (parece ser essa a sua razão maior), a tarefa do intérprete estará "facilitada": de um lado, decidir-se-á casos dedutivamente; de outro, será possível decidir milhares de processos de uma só vez. Em ambas as hipóteses, soçobra a situação concreta.

Afinal, como se diz na teoria da argumentação jurídica (para ficar nessa importante postura que pretende dar respostas ao problema da indeterminabilidade do direito nesta quadra da história), para "casos fáceis", basta a subsunção (sic). E tudo começa(rá) de novo...! Por isso, a necessidade - e não a mera possibilidade - de alcançar respostas corretas em direito.

\section{APORTES FINAIS: UM DECÁLOGO HERMENÊUTICO}

Uma reflexão crítica sobre a aplicação do direito não pode, pois, abrir mão dos pressupostos hermenêuticos que apontam para a superação do esquema sujeito-objeto, ${ }^{11}$ dos "modelos" (solipsistas) de juiz "criados" para "enfrentar" as agruras da indeterminabilidade dos textos jurídicos na era dos princípios, assim como dos diversos dualismos próprios dos paradigmas metafísicos objetificantes (clássico e da filosofia da consciência). É preciso insistir nisso: consciência e mundo, linguagem e objeto, sentido e percepção, teoria e prática, texto e norma, vigência e validade, regra e princípio, casos simples e casos difíceis, discursos de justificação e discursos de aplicação, são dualismos que se instalaram no nosso imaginário, sustentados pelo esquema sujeito-objeto.

Não se quer dizer, entretanto, que as diversas teorias do direito não estejam preocupadas em buscar respostas ao problema da crise paradigmática que atravessa o direito. Mas, nessa busca de soluções para os problemas da metodologia do direito, o que não se pode fa- 
zer é "mixar" teorias, principalmente entre posturas procedimentaisargumentativas e perspectivas conteudísticas-ontológicas, para citar apenas estas.

Permito-me, nesse sentido, lançar dez pontos que deixam nítida essa impossibilidade de mixagens metodológicas:

Primeiro, não se pode confundir hermenêutica com teoria da argumentação jurídica, isto é, hermenêutica (filosófica) não é similar a nenhuma teoria da argumentação ${ }^{12}$ (portanto, não é possível com ela fundir - por mais sofisticadas e importantes que sejam - as teses de Alexy [2001], Atienza [2003], e Günther [2004]), para falar apenas destes. Por isso, ainda neste primeiro ponto do decálogo, não posso esquecer de repetir a denúncia que há muito venho fazendo: a de que o Direito Constitucional (especialmente ele) foi "tomado" - aqui em terrae brasilis - por diversas "teorias dos princípios", por vezes autodenominadas "teorias da argumentação jurídica" (que, entretanto, não guardam fidelidade às TAJ's mencionadas anteriormente), sendo raro, nestes dias, encontrar constitucionalistas que não se rendam à distinção estrutural regra-princípio e à ponderação de valores (alguns ainda falam em "ponderação de interesses"). Claro que isso também acontece com os processualistas, bastando, para tanto, examinar os projetos dos novos Códigos de Processo Civil e Penal. A partir dessa mixagem teórica, são desenvolvidas/seguidas diversas teorias/teses por vezes incompatíveis entre si. Além da ponderação de princípios - que, saliente-se, no plano das práticas cotidianas dos juristas, não tem qualquer relação com a "ponderação de princípios" proposta por Alexy -, há quem defenda a ponderação de regras. Neste último caso, o que chama mais atenção é o fato de a ponderação ser um dos fatores centrais que marcam a distinção entre regras e princípios de Robert Alexy (princípios se aplicam por ponderação e regras por subsunção, é uma das máximas alexyanas). Daí a indagação: se a ponderação é o procedimento do qual o resultado será uma regra posteriormente subsumida ao caso concreto, o que temos como resultado da "ponderação de regras"? Uma "regra" da regra? Como fica, portanto, em termos práticos, a distinção entre regras e princípios, uma vez que deixa de ter razão de ser a distinção entre subsunção e ponderação? No Brasil, a ponderação aparece como procedimento generalizado de 
aplicação do direito. Isso é um equívoco. Ou seja, em todo e qualquer processo aplicativo, haveria a necessidade de uma "parada" para que se efetuasse a ponderação. Tal empresa - estender a ponderação para a aplicação de regras - se mostra destituída de sentido prático, visto que da regra irá resultar outra regra, essa, sim, aplicável ao caso, além de apontar para os equívocos na recepção da teoria alexyana entre os autores brasileiros. Na maior parte das vezes, os adeptos da ponderação não levam em conta a relevante circunstância de que é impossível fazer uma ponderação que resolva diretamente o caso. A ponderação - nos termos propalados por seu criador, Robert Alexy - não é uma operação em que se colocam os dois princípios em uma balança e se aponta para aquele que "pesa mais" (sic), algo do tipo "entre dois princípios que colidem, o intérprete escolhe um" (sic). Nesse sentido é preciso fazer justiça a Alexy: sua tese sobre a ponderação não envolve essa "escolha direta";

segundo, quando se diz que a Constituição e as leis são constituídas de plurivocidades sígnicas (textos "abertos", palavras vagas e ambíguas, etc.), tal afirmativa não pode dar azo a que se diga que sempre há várias interpretações e, portanto, que o direito permite múltiplas respostas, circunstância que, paradoxalmente, apenas denuncia - e aqui chamo à colação as críticas de Dworkin à Hart - as posturas positivistas que estão por trás de tais afirmativas;

terceiro, quando, por exemplo, Gadamer confronta o método, com o seu Verdade e Método, não significa que a hermenêutica seja relativista e permita interpretações discricionárias/arbitrárias;

quarto, na mesma linha, quando se fala na invasão da filosofia pela linguagem, mais do que a morte do esquema sujeito-objeto, isso quer dizer que não há mais um sujeito que assujeita o objeto (subjetivismos/axiologismos que ainda vicejam no campo jurídico) e tampouco objetivismos; ${ }^{13}$

quinto, quando se popularizou a máxima de que "interpretar é aplicar" e que "interpretar é confrontar o texto com a realidade", não significa que texto e realidade sejam coisas que subsistam por si só ou que sejam "apreensíveis" isoladamente, sendo equivocado pensar, portanto, que interpretar é algo similar a "fazer acoplamentos entre um texto jurídico e os fatos"; 
sexto, de igual maneira, quando se popularizou a assertiva de que texto não é igual à norma e que a norma é o produto da interpretação do texto, nem de longe quer dizer que o texto não vale nada ou que norma e texto sejam "coisas à disposição do intérprete", ou, ainda, que o intérprete possui arbitrariedade para a "fixação da norma" (sentido do texto);

sétimo, se texto e sentido do texto não são a mesma coisa, tal circunstância não implica a afirmação de que estejam separados (cindidos) ou que o texto contenha a própria norma, mas sim, que apenas há uma diferença (ontológica) entre os mesmos; é preciso compreender que a norma é o texto em forma de enunciados, em que o conteúdo veritativo não é nada mais do que a dimensão predicativa, isto é, aquilo que se diz sobre ele;

oitavo, é um equívoco pregar que o texto jurídico é apenas "a ponta do iceberg", e que a tarefa do intérprete é a de revelar o que está "submerso" (por exemplo, os "valores" da sociedade - sic), porque pensar assim é dar azo à discricionariedade e ao decisionismo, características do positivismo;

nono, não pode restar dúvida de que tanto a separação como a dependência/vinculação entre direito e moral estão ultrapassadas, em face daquilo que se convencionou chamar de institucionalização da moral no direito (esta é uma fundamental contribuição de Habermas para o direito: a co-originariedade entre direito e moral), circunstância que reforça, sobremodo, a autonomia do direito. Isto porque a moral regula o comportamento interno das pessoas, só que esta "regulação" não tem força jurídico-normativa. O que tem força vinculativa, cogente, é o direito, que recebe conteúdos morais (apenas) quando de sua elaboração legislativa (veja-se, a seguir, essa discussão no subtítulo que trata do criptograma da discricionariedade). Observemos: é por isso que o Estado Democrático de Direito não admite discricionariedade (nem) para o legislador, porque ele está vinculado a Constituição (lembremos sempre a ruptura paradigmática que representou o constitucionalismo compromissório e social). $\mathrm{O}$ "constituir" da Constituição é a obrigação suprema do direito. É, pois, a virtude soberana (parafraseando Dworkin). A partir da feitura da lei, a decisão judicial passa a ser racionalizada na lei, que 
quer dizer, "sob o comando da Constituição" e não "sob o comando das injunções pessoais-morais-políticas do juiz ou dos tribunais". Essa questão é de suma importância, na medida em que, ao não mais se admitir a tese da separação (e tampouco da vinculação), não mais se corre o risco de colocar a moral como corretiva do direito. E isso terá consequências enormes da discussão "regra-princípio".

Décimo, como consequência, nos casos assim denominados de "difíceis", não é mais possível "delegar" para o juiz a sua resolução. Isto porque não podemos mais aceitar que, em pleno Estado Democrático de Direito, ainda se postule que a luz para determinação do direito in concreto provenha do protagonista da sentença. Do mesmo modo, a ideia de imparcialidade pura do juiz ou o uso de estratégias argumentativas para isentar a responsabilidade do julgador no momento decisório podem levar à introdução de argumentos de política na decisão jurídica. Nesse sentido são precisas as afirmações de Dworkin:

"A política constitucional tem sido atrapalhada e corrompida pela ideia falsa de que os juízes (se não fossem tão sedentos de poder) poderiam usar estratégias de interpretação constitucional politicamente neutras. Os juízes que fazem eco a essa ideia falsa procuram ocultar até de si próprios a inevitável influência de suas próprias convicções, e o que resulta daí é uma suntuosa mendacidade. Os motivos reais das decisões ficam ocultos tanto de uma legítima inspeção pública quanto de um utilíssimo debate público. Já a leitura moral prega uma coisa diferente. Ela explica porque a fidelidade à Constituição e ao direito exige que os juízes façam juízos atuais de moralidade política e encoraja assim a franca demonstração das verdadeiras bases destes juízos, na esperança de que os juízes elaborem argumentos mais sinceros, fundados em princípios, que permitam ao público participar da discussão"14.

Isso significa que, para além da cisão estrutural entre casos simples e casos difíceis, não pode haver decisão judicial que não seja fundamentada e justificada em um todo coerente de princípios que repercutam a história institucional do direito. Desse modo, tem-se por superada a discricionariedade a partir do dever fundamental de resposta correta que recai sobre o juiz no contexto do paradigma do Estado Democrático de Direito. 
Não posso esquecer, aqui, de repetir a denúncia que há muito venho fazendo: a de que o Direito Constitucional (especialmente ele) foi "tomado" - aqui em terrae brasilis - por diversas "teorias dos princípios" - por vezes autodenominadas "teorias da argumentação jurídica" -, sendo raro, nestes dias, encontrar constitucionalistas que não se rendam à distinção estrutural regra-princípio e à ponderação de valores (alguns ainda falam em "ponderação de interesses"). A partir dessa mixagem teórica, são desenvolvidas/seguidas diversas teorias/ teses por vezes incompatíveis entre si. Além da ponderação de princípios, há quem defenda a ponderação de regras. Neste último caso, o que chama mais atenção é o fato de a ponderação ser um dos fatores centrais que marcam a distinção entre regras e princípios de Robert Alexy (princípios se aplicam por ponderação e regras por subsunção, é uma das máximas alexyanas). E mais: se a ponderação é o procedimento do qual o resultado será uma regra posteriormente subsumida ao caso concreto, o que temos como resultado da "ponderação de regras"? Uma "regra" da regra? Como fica, portanto, em termos práticos, a distinção entre regras e princípios, uma vez que deixa de ter razão de ser a distinção entre subsunção e ponderação? No Brasil, a ponderação aparece como procedimento generalizado de aplicação do direito. Isso é um equívoco. Ou seja, em todo e qualquer processo aplicativo, haveria a necessidade de uma "parada" para que se efetuasse a ponderação. Tal empresa - estender a ponderação para a aplicação de regras - se mostra destituída de sentido prático, visto que da regra irá resultar outra regra, essa, sim, aplicável ao caso, além de apontar para os equívocos na recepção da teoria alexyana entre os autores brasileiros.

Na maior parte das vezes, os adeptos da ponderação não levam em conta a relevante circunstância de que é impossível fazer uma ponderação que resolva diretamente o caso. A ponderação - nos termos propalados por seu criador, Robert Alexy - não é uma operação em que se colocam os dois princípios em uma balança e se aponta para aquele que "pesa mais" (sic), algo do tipo "entre dois princípios que colidem, o intérprete escolhe um" (sic). Nesse sentido é preciso fazer justiça a Alexy: sua tese sobre a ponderação não envolve essa "escolha direta".

Em outras palavras, não é possível servir a vários senhores da ciência ao mesmo tempo. Trata-se de uma opção paradigmática, o que 
acarreta uma impossibilidade de misturar, por exemplo, posturas ainda assentadas no esquema sujeito-objeto (em menor ou maior grau) e posturas antiepistemológicas. Definitivamente, hermenêutica não é teoria da argumentação, do mesmo modo que verdade não é consenso. Não é possível lançar mão tão-somente das "partes nobres" de cada teoria (ou paradigma), descartando as insuficiências.

Mas, atenção: a hermenêutica não afasta a epistemologia. Entretanto, o que não é possível fazer é confundir os níveis nos quais nos movemos. Ou seja - deixo isso claro em meu Verdade e Consenso -, quando explícito o (já) compreendido, esse processo se dá no nível lógico-argumentativo, e não filosófico. E, insista-se: filosofia não é lógica. Esse "proceder epistemológico" é antecipado; não se confunde com o próprio conhecimento. Pela hermenêutica, fazemos uma fenomenologia do conhecimento. Não é uma coisa concreta. É, sim, a descrição da autocompreensão que opera na compreensão concreta. Na explicitação é que haverá o espaço de uma teoria do conhecimento.

Na era das Constituições compromissórias e sociais (e dirigentes), enfim, em pleno pós-positivismo, uma hermenêutica jurídica capaz de intermediar a tensão inexorável entre o texto e o sentido do texto não pode continuar a ser entendida como uma teoria ornamental do direito, que sirva tão somente para colocar "capas de sentido" aos textos jurídicos. No interior da virtuosidade do círculo hermenêutico, o compreender não ocorre por dedução. Consequentemente, o método (o procedimento discursivo) sempre chega tarde, porque pressupõe saberes teóricos separados da "realidade". Antes de argumentar, o intérprete já compreendeu.

De todo modo, devemos reconhecer que, visando à realização das promessas incumpridas da modernidade, as diversas teorias críticas (teoria do discurso habermasiana, as diversas teorias da argumentação, a hermenêutica filosófica, a metódica estruturante, etc.), todas perfeitamente inseridas no paradigma do Estado Democrático de Direito, têm, inequivocamente, um objetivo comum: a superação do positivismo jurídico e do dogmatismo que se enraizou na doutrina e na jurisprudência, responsáveis em grande medida pela inefetividade da Constituição (circunstância que assume foros de dramaticidade em 
países de modernidade tardia como o Brasil). Cada uma das correntes filosóficas ou teorias, ao seu modo, apontam as possíveis saídas para a superação da crise do direito brasileiro, cada vez mais aguda. Nessa intensa procura, há algo que é inacessível e isto parece incontornável. Ou algo que é incontornável e que, por isso, inacessível...

Nesse contexto do cotejo das diversas teorias, é preciso trazer à lume uma questão de extrema relevância, quem vem confundindo a comunidade jurídica, fruto de diferentes equívocos acerca da relação "positivismo/pós-positivismo", além da necessária questão relacionada ao papel desempenhado pelo juiz diante da relação entre os Poderes do Estado. A dogmática jurídica - compreendida lato sensu (dos críticos aos tradicionais conservadores) - não conseguiu ainda construir os alicerces para a compreensão do que seja um paradigma e o papel do positivismo jurídico (e o que seja, efetivamente, uma "postura positivista"). Não é difícil constatar a confusão entre os vários tipos de positivismos. A maioria dos juristas ainda combate o positivismo primitivo (exegético).

Com efeito, em julgamentos nos tribunais e em conferências empolgadas, lemos e ouvimos que os juízes não devem "cumprir a letra 'fria' (sic) da lei" e que há(veria) dois tipos de juízes: o positivista, que se apega à lei e o crítico pós-positivista, que se utiliza dos princípios (sic). Segundo se diz por aí, o primeiro tipo de juiz deve "desaparecer"; o segundo, o dos princípios, é o modelo ideal. Só que, nesse último caso, ao incentivarem a "busca dos valores", seus autores mal sabem que, o que estão fazendo, é uma vulgata do velho positivismo fático...! E, com isso, fragilizando a autonomia do direito. Mas, mais do que isso, fragilizam a divisão entre as funções e poderes do Estado nesta fase da história.

Ora, desde quando obedecer uma lei democrática nos seus mínimos detalhes é "ser um positivista"? Na verdade, confundem-se conceitos. Vejamos: positivismo exegético (que era a forma do positivismo primitivo) é uma coisa distinta, porque separava direito e moral, além de confundir texto e norma, lei e direito, ou seja, tratava-se da velha crença - ainda presente no imaginário dos juristas - em torno da proibição de interpretar, corolário da vetusta separação entre fato e direito, algo que 
nos remete ao período pós-revolução francesa e todas as consequências políticas que dali se seguiram. Depois veio o positivismo normativista, seguido das mais variadas formas e fórmulas que - identificando (arbitrariamente) a impossibilidade de um "fechamento semântico" do direito - relegou o problema da interpretação jurídica a uma "questão menor" (lembremos, aqui, de Kelsen): o problema do direito não está no modo como os juízes decidem, mas, simplesmente, nas condições lógico-deônticas de validade das "normas jurídicas".

Mas, uma coisa todos esses positivismos têm até hoje em comum: a discricionariedade (que leva à arbitrariedade, aos decisionismos, ativismos, etc). E isso se deve a um motivo muito simples: a tradição continental, pelo menos até o segundo pós-guerra, não havia conhecido uma Constituição normativa, invasora da legalidade e fundadora do espaço público democrático. Isso tem consequências drásticas para a concepção do direito como um todo! Quero dizer: saltamos de um legalismo rasteiro que reduzia o elemento central do direito, ora a um conceito estrito de lei (como no caso dos códigos oitocentistas, base para o positivismo primitivo), ora a um conceito abstrato-universalizante de norma (que se encontra plasmado na ideia de direito presente no positivismo normativista), para uma concepção da legalidade que só se constitui sob o manto da constitucionalidade. Afinal - e me lembro aqui de Elias Dias -, não seríamos capazes, nesta quadra da história, de admitir uma legalidade inconstitucional.

Eis o "ovo da serpente". Obedecer "à risca o texto da lei democraticamente construída" (já superada - a toda evidência - a questão da distinção entre direito e moral) não tem nada a ver com a "exegese" à moda antiga (positivismo primitivo). No primeiro caso, a moral ficava de fora; agora, no Estado Democrático de Direito, ela é co-originária. Falamos hoje, pois, de uma "outra" ou de uma nova legalidade. Como exemplo, cito a "literalidade do art. 212 do CPP (na nova redação trazida pela Lei n. 11.690/08, que inverte a ordem das perguntas às testemunhas). Ora, aplicar o dispositivo em tela é não só obedecer (também) "literalmente" a Constituição, como institucionalizando o sistema acusatório, tão reclamado pelos processualistas penais. A legalidade reclamada, neste 
caso, é uma legalidade constituída a partir dos princípios que são o marco da história institucional do direito; uma legalidade, enfim, que se forma no horizonte daquilo que foi, prospectivamente, estabelecido pelo texto constitucional.

Por tudo isso, "cumprir a letra da lei" significa sim, nos marcos de um regime democrático como o nosso, um avanço considerável. A isso, deve-se agregar a seguinte consequência: tanto aquele que diz que texto e norma (ou vigência e validade) são a mesma coisa como aquele que diz que estão "descolados" (no caso, as posturas axiologistas, realistas, etc.), são positivistas. Para ser mais simples: Kelsen, Hart e Ross foram todos positivistas. Como positivistas são hoje os juristas que apostam na discricionariedade judicial...! Ou em ativismos judiciais irresponsáveis (o que dá no mesmo). Seja isso para o bem ou para o mal.

\section{REFERÊNCIAS}

ALEXY, Robert. Teoria da argumentação jurídica. São Paulo: Landy, 2001.

ARNAUD, André-Jean. Le courrier du CNRS. Les sciences du droit, abril de 1990.

ATIENZA, Manuel. As razões do Direito. 3. ed. São Paulo: Landy, 2003.

DWORKIN, Ronald. Law's empire. London: Fontana Press, 1986.

. Taking Rights Seriously. Cambridge, Massachussets: Harvard University Press, 1977.

. Direito de liberdade. Leitura moral da constituição americana. São Paulo: Martins Fontes, 2006.

GADAMER, Hans-Georg. Wahrheit und methode, Ergänzungen Register. Tübingen, J. C. B. Mohr (Paul Siebeck), 1993. 
GADAMER, Hans-Georg. Wahrheit und methode. Grundzüge einer philosophischen Hermeneutik. Tübingen, J. C. B. Mohr (Paul Siebeck), 1990.

GRONDIN, Jean. Einführung zu gadamer. Tübingen, J. C. B. Mohr (Paul Siebeck), 2000.

GÜNTHER, Klaus. Teoria da argumentação no direito e na moral: justificação e aplicação. São Paulo: Landy, 2004

HABERMAS, Jürgen. Faktizität und geltung. Beiträge zur Diskurstheorie des Rechts und des demokratischen Rechsstaats. Frankfurt am Main, Suhrkamp, 1992.

HEIDEGGER, Martin. Sein und zeit. Siebzehnte Auflage. Tübingen, Max Niemayer, Verlag Tübingen, 1993.

HOMMERDING, Adalberto Narciso. Fundamentos para uma compreensão hermenêutica do Processo Civil. Porto Alegre: Livraria do Advogado, 2007.

MOREIRA, Nelson Camatta. Fundamentos de uma teoria da constituição dirigente. Florianópolis: Conceito Editorial, 2010.

MOTTA, Francisco J. Borges. Levando o direito a sério: uma crítica hermenêutica ao protagonismo judicial. Florianópolis: Conceito Editorial, 2010.

OLIVEIRA, Manfredo Araújo de. Reviravolta Linguístico-pragmática na Filosofia contemporânea. São Paulo: Loyola, 2001.

OST, François. Júpiter, Hércules, Hermes: tres modelos de juez. In: Doxa, Cuadernos de Filosofia del Derecho, n. 14, Alicante, 1993.

RAMIRES, Maurício. Crítica à aplicação de precedentes no direito brasileiro. Porto Alegre: Livraria do Advogado, 2010.

STRECK, Lenio Luiz. Verdade e consenso. Constituição, Hermenêutica e Teorias Discursivas. Da possibilidade à necessidade de respostas corretas em direito. 2. ed. Rio de Janeiro: Lumen Juris, 2007. 


\section{TOMAZ DE OLIVEIRA, Rafael Tomaz. Decisão judicial e o conceito de princípio. A hermenêutica e a (in)determinação do direto. Porto Alegre: Livraria do Advogado, 2008.}

\section{NOTAS}

1 Permito-me remeter o leitor para o meu Verdade e Consenso, 3. ed (Lumen Juris, 2009) e $4^{\mathrm{a}}$. Ed (Saraiva, 2011, onde essa problemática é esmiuçada cum granu salis.

2 De que modo se pode falar em "valores" em sociedades complexas ("pós-tradicionais", como se refere Habermas) como as nossas? Não há como defender um "método de ponderação", porque ele supõe valores intersubjetivamente compartilhados; além disso, nega o caráter deontológico do direito, colocando este sob a lógica gradual dos valores (ver HABERMAS, Jürgen. A inclusão do outro. São Paulo: Loyola, 2002, p. 355 et seq.). Isso só é possível porque fundado no primeiro ponto, isto é, se "a" sociedade compartilha valores comuns, pode-se escaloná-los de forma gradual. O problema é que, se não há tal compartilhamento, o que resta, ao fim e ao cabo, além da violação ao "código" (Luhmann) próprio do Direito, é o "decisionismo" judicial. Ademais, se o juiz se coloca como crítico das opções do legislador, para lhe definir "sentidos" (e. g., interpretação conforme a Constituição), a partir da valoração dos valores constitucionais, perdem-se os parâmetros de controle de sua atividade (Ingeborg Maus). O que é interessante sobre esta "adoção acrítica" (ao contrário, entusiasta!) da jurisprudência dos valores germânicos é que, na Alemanha, a mesma sofre duras críticas. Ingeborg Maus fala do mal que se abateu sobre o Judiciário de seu país desde o final da Segunda Guerra, dizendo que o mesmo assumiu o "superego de uma sociedade órfã" (MAUS, Ingeborg. Judiciário como Superego da Sociedade: o papel da atividade jurisprudencial na "sociedade órfã". Novos Estudos CEBRAP, São Paulo, n. 58, pp. 183-202, 2000). Em suas palavras: “A eliminação de discussões e procedimentos no processo de construção política do consenso [...], é alcançada por meio da centralização da 'consciência' social na Justiça. [...] Quando a Justiça ascende ela própria à condição de mais alta instância moral da sociedade, passa a escapar de qualquer mecanismo de controle social" (pp. 186-187, grifos nossos). Na mesma linha, Habermas também tece críticas a partir, inclusive, de outros constitucionalistas, como Denninger, Dieter Grimm e Böckenförde (cf. HABERMAS, Jürgen. Facticidad y validez: sobre el derecho y el estado democrático de derecho en términos de teoría del discurso. Madrid: Trotta, 1998, p. 317 e 322).

3 Importante registrar um esclarecimento: quando falo aqui em uma ênfase semântica, estou me referindo explicitamente ao problema da interpretação do direito tal qual é descrito por Kelsen no fatídico capítulo VIII de sua Reine Rechtslehre. Para compreendermos bem essa questão, é preciso insistir em um ponto: há uma cisão em Kelsen entre direito e ciência do direito que irá determinar, de maneira crucial, seu conceito de interpretação. De fato, também a interpretação, em Kelsen, será fruto de uma cisão: interpretação como ato de vontade e interpretação como ato de conhecimento. A interpretação como ato de vontade produz, no momento de sua "aplicação", normas. A descrição dessas normas de forma objetiva e neutral - interpretação como ato de conhecimento - produz proposições. Dado à característica relativista da moral kelseniana, as normas - que exsurgem de um ato de vontade - terão sempre um espaço de mobilidade sob o qual se movimentará o intérprete. Esse espaço de movimentação é derivado, exatamente, do problema semântico que existe na aplicação de um signo linguístico - através do qual a norma superior se manifesta - aos objetos do mundo concreto - que serão afetados pela criação de uma nova norma. Por outra banda, a interpretação como ato de conhecimento - que descreve no plano de uma metalinguagem as normas produzidas pelas autoridades jurídicas - produz proposições que se relacionam entre si de uma maneira estritamente lógicoformal. Vale dizer, a relação entre as proposições são, essas sim, meramente sintáticas. Minha preocupação, contudo, não é dar conta dos problemas sistemáticos que envolvem o projeto 
kelseniano de ciência jurídica. Minha questão é explorar e enfrentar o problema lançado por Kelsen e que perdura de um modo difuso e, por vezes, inconsciente no imaginário dos juristas: a ideia de discricionariedade do intérprete ou do decisionismo presente na metáfora da "moldura da norma". É nesse sentido que se pode afirmar que, no que tange à interpretação do direito, Kelsen amplia os problemas semânticos da interpretação, acabando por ser picado fatalmente pelo "aguilhão semântico" de que fala Ronald Dworkin.

4 Essa questão é extremamente relevante, porque a perspectiva sistêmica, ao decretar a "morte" do sujeito", aproxima-a dos modelos desconstrutivistas, isto é, a superação do esquema sujeito-objeto acaba anulando o próprio sujeito. Por isso, é necessário insistir, a partir, evidentemente, de um olhar heideggero-gadameriano, que a invasão da filosofia pela linguagem e o resgate do mundo prático não representou a morte do sujeito, e, sim, apenas a morte da subjetividade assujeitadora (certeza de si do pensamento pensante).

5 ARNAUD, André-Jean. Le courrier du CNRS. Les sciences du droit, abril de 1990, p. 81.

6 No Brasil, Wálber Araujo Carneiro, não obstante veja no Hércules de Dworkin a figura de um juiz não-arbitrário, propõe a alegoria de um juiz adaptado às condições sistêmico-institucionais do civil law e, em contraposição à leitura pós-moderna de Ost, concebe o seu "juiz Hermes" em uma "morada mais familiar", isto é, no contexto hermenêutico-filosófico. O juiz Hermes, proposto por Wálber, "é responsável por traduzir juridicamente aquilo que compreende a partir do mundo da vida". Embora Hermes tenha sido preparado para se movimentar no mundo institucionalizado do direito, isso não fez dele um "estrangeiro", pois "seu cotidiano é vivido no seu mundo originário". A releitura da alegoria de Hermes trazida por Wálber enfrenta ainda a formação acadêmica de Hermes, em uma ácida crítica ao modelo de ensino jurídico no Brasil, bem como o "método" heterorreflexivo por ele proposto em sua obra. CARNEIRO, Wálber Araujo. Hermenêutica jurídica heterorreflexiva, 2011, p. 273-280.

7 STRECK, Lênio Luiz. Verdade e consenso. 3. ed. Rio de Janeiro: Lumen Juris, 2009 e STRECK, Lênio Luiz. Verdade e consenso. 4. ed. São Paulo: Saraiva, 2011.

8 DWORKIN, Ronald. Law's empire. London: Fontana Press, 1986; DWORKIN, Ronald. Taking Rights Seriously. Cambridge, Massachussets: Harvard University Press, 1977.

9 Parece despiciendo referir que a resposta correta não é, jamais, uma resposta definitiva. Do mesmo modo, a pretensão de se buscar a resposta correta não possui condições de garanti-la. Corre-se o risco de se produzir uma resposta incorreta. Mas o fato de se obedecer à coerência e a integridade do direito, a partir de uma adequada suspensão de pré-juízos advindos da tradição, já representa o primeiro passo no cumprimento do direito fundamental que cada cidadão tem de obter uma resposta adequada a Constituição.

10 Cf. Jurisprudência do Supremo Tribunal Federal do Brasil, DJ 25.10.96.

11 De se consignar que há muitos trabalhos - produzidos sob minha orientação - que procuram aproximar as conquistas da filosofia hermenêutica e da hermenêutica filosófica do direito. Nesse sentido, é importante citar o núcleo de estudos hermenêuticos - Dasein - que, no âmbito do PPG em direito da Unisinos-RS, desenvolve atualmente um profícuo trabalho que procura enquadrar, hermenêutica e criticamente, fenômenos como o Ativismo Judicial, a Judicialização da Política e o problema da interpretação da Constituição, nesses mais de vinte anos de constitucionalismo democrático no Brasil. Esse grupo conta com a participação da mestranda Clarissa Tassinari, dos mestrandos Danilo Pereira Lima e Santiago Artur Berger Sito, além dos bolsistas de Iniciação Científica Rafael Köche e Fabiano Müller. O Dasein também foi o espaço que fomentou os trabalhos de André Karam Trindade, Fausto Santos de Moraes e Rafael Tomaz de Oliveira. Há ainda, também, publicações importantes que foram forjadas na trilha daquilo que venho denominando "nova crítica do Direito". Nesse sentido, Cf. TOMAZ DE OLIVEIRA, Rafael Tomaz. Decisão Judicial e o Conceito de Princípio. A hermenêutica e a (in) determinação do direto. Porto Alegre: Livraria do Advogado, 2008, em que este procura identificar o sincretismo conceitual que existe em torno do conceito de princípio procurando, a partir do paradigma da fenomenologia hermenêutica, um modo adequado de abordagem do conceito de princípio em tempos de constitucionalismo compromissório. Trata-se de obra importante para enfrentar o problema daquilo que venho chamando de pan-principiologismo. No campo do direito processual, também há importantes contribuições desenvolvidas a partir da 
hermenêutica filosófica e da filosofia hermenêutica. Nesse sentido, Cf. MOTTA, Francisco J. Borges. Levando o direito a sério: uma crítica hermenêutica ao protagonismo judicial. Florianópolis: Conceito Editorial, 2010, que procurada enquadrar o problema do protagonismo judicial no âmbito da teoria processual a partir da teoria integrativa de Ronald Dworkin, agregada pela intersecção com a obra de Hans-Georg Gadamer, na linha daquilo que, em Verdade e Consenso venho trabalhando em termos de uma imbricação entre Gadamer e Dworkin. Também a obra de HOMMERDING, Adalberto Narciso. Fundamentos para uma compreensão hermenêutica do processo civil. Porto Alegre: Livraria do Advogado, 2007, que procura situar o campo da teoria processual em um ambiente hermeneuticamente adequado. Nesse sentido, Hommerding realiza uma desconstrução dos modelos liberais-individualista de teoria processual, propondo, a partir dos aportes da filosofia hermenêutica, uma compreensão hermenêutica do processo civil. Destaco, ainda, o trabalho de RAMIRES, Maurício. Crítica à aplicação de precedentes no direito brasileiro. Porto Alegre: Livraria do Advogado, 2010, que procura, a partir de uma crítica ao sincretismo praticado no Brasil entre as tradições da civil Law e da common Law, efetuar uma crítica ao modo como os precedentes judiciais são aplicados em terrae brasilis. É sempre importante lembrar que a jurisprudência brasileira tende a tratar os casos julgados pelos tribunais como fórmulas prontas - verdadeiras capas de sentido - passíveis de serem aplicadas aos casos futuros a partir de um modelo prêt-à-porter. A hermenêutica mostra, aqui, toda singularidade que brota a partir da análise do caso e a complexidade que toma conta do processo de interpretação do direito, que deve estar pautado pelos deveres de integridade e coerência. Importante também lembrar o trabalho de MOREIRA, Nelson Camatta. Fundamentos de uma teoria da constituição dirigente. Florianópolis: Conceito Editorial, 2010, no interior do qual o autor procura, no campo da Teoria Constitucional, encontrar um fundamento para a experiência do dirigismo constitucional, a partir da filosofia de Charles Taylor - autor que possui profundo vínculo com a hermenêutica no modo como ela se desdobrou no século XX. Enfim, há ainda uma centena de teses e dissertações que ventilam as propostas e os estudos desenvolvidos no âmbito do PPG em Direito da Unisinos, particularmente ligados ao Dasein - Núcleo de Estudos Hermenêuticos, que funciona sob a minha coordenação. O fio condutor que une todos estes trabalhos pode ser traçado a partir da descoberta do caráter projetivo da interpretação; a defesa do caráter constitutivo da linguagem; e, em consequência disso tudo, a superação da relação sujeito-objeto pela intersubjetividade que instaura os sentidos do processo compreensivo.

12 Tenho sustentado que as teorias da argumentação não superaram o paradigma representacional (sujeito-objeto) e que a ponderação de que fala Alexy (em especial, ele) é um modo de repristinação da (velha) discricionariedade positivista, tese que, aliás, as teorias da argumentação afirmam combater. Os sintomas desses problemas podem ser percebidos, v.g., a partir da - para mim, indevida - cisão entre casos fáceis e casos difíceis, quando Alexy (e seus seguidores, especialmente no Brasil) dizem que os easy cases são resolvidos por subsunção (ou dedução) e os hard cases através da ponderação, momento em que os princípios são chamados à colação.

13 Despiciendo lembrar que a expressão "objetivismos" ou "objetivista" provém do paradigma aristotélico-tomista e não da dicotomia "subjetivistas ("vontade do legislador") - "objetivistas" (vontade da lei). Embora se possa fazer uma relação entre os termos - relação essa que necessitaria de uma ampla explicitação no plano da teoria do direito - , na verdade estou a tratar de um paradigma filosófico (que teima em não desaparecer) e não propriamente da contraposição das referidas posturas surgidas no século XIX.

\section{Artigo recebido em: 10/02/2011 \\ Aprovado para publicação em: 17/02/2011}

